\title{
大腸低分化腺癌の臨床病理学的検討：充実型，非充実型 低分化腺癌の分類法の予後因子としての重要性
}

\author{
中村 隆俊 大谷 剛正三富 弘之 ${ }^{1)}$ 金澤 秀紀 根本一彦 \\ 国場 幸均佐田 美和 ${ }^{2)}$ 井原 厚 ${ }^{3)}$ 柿田 章 ${ }^{3)}$ \\ 北里大学東病院消化器外科 \\ 1)北里大学東病院病理 \\ 2) 北里大学東病院消化器内科 \\ 3) 北里大学病院外科
}

\begin{abstract}
大腸低分化腺癌は頻度が低いため, 臨床病理学的に十分な検討がなされていない.そこで, 低分化腺癌 の臨床病理学的特徵を抽出するために，1986 年から 1999 年までに当院で経験した低分化腺癌 82 例につ いて, 同時期の分化型腺癌 1,003 例と臨床病理学的に比較し, さらに, 低分化腺癌を充実型と非充実型に 西分類し検討を加えた。低分化腺癌は高・中分化腺癌に比べ腫瘍径が大きく, リンパ節・肝・腹膜転移陽 性例が多く（p<0.01 0.0001），予後不良で（logrank test， p<0.0001），5年生存率は低分化腺癌 $47 \% ，$ 中分化腺癌 $66 \%$, 高分化腺癌 $75 \%$ であった。また非充実型低分化腺癌は充実型に比べ有意にリンパ節・ 肝転移が多く $(p<0.05)$, 予後不良で $(p<0.01) ， 5$ 年生存率は非充実型 $37 \%$ ，充実型 68\%であった.Cox の回帰分析では, 独立した予後不良因子の 1 つとして非充実型が抽出され, 低分化腺癌の亜分類は予後を 推定する上で有用な指標と考えられた。
\end{abstract}

索引用語：大腸癌, 低分化腺癌, 充実·非充実型発育, 予後, 多変量解析

はじめに

大腸癌のほとんどが高分化，中分化腺癌であり， 低分化腺癌の頻度は全体の $1.7 \sim 7.4 \%$ と比較的稀で あり ${ }^{1) 99}$ ，そのため，臨床的に十分な検討がなされ ていない，一方，胃癌では低分化腺癌についての検 討は多く ${ }^{10 \sim 13)}$, 既に充実型・非充実型の低分化腺癌 亜分類が胃癌取り扱い規的に採用されており ${ }^{14)}$ ，充 実型は静脈侵襲が高度で, 肝転移が多くみられ ${ }^{10.12)}$, 非充実型に比べ予後不良と報告されている ${ }^{13)}$. そこ で，今回われわれは，大腸低分化腺癌を高分化，中 分化腺癌と比較検討し, さらに低分化腺澏を組織学 的に充実型と非充実型の 2 つに亜分類し，その両者 について臨床病理学的特徴を比較検討した。

\section{対象および方法}

対象は，1986 年 4 月から 1999 年 12 月までの 14 年間に当院にて経験した大腸癌切除症例 1126 例で
あり，その内訳は低分化腺癌 82 例 (7.3\%), 高分化 腺癌 631 例 $(56.0 \%)$, 中分化腺癌 372 例 $(33.0 \%)$, 粘液癌 36 例 $(3.2 \%)$ ，未分化癌 4 例 $(0.4 \%)$ ，印環細 胞癌 1 例 $(0.1 \%)$ で, 遺伝性非ポリポーシス大腸煰 症例は 1 例もなかった。なお組織型の分類は大腸癌 取り扱い規約 ${ }^{15} に$ 従い, 最も優勢な分化度をもって その組織型とした。さらに低分化腺癌を胃癌取り扱 い規約 ${ }^{14)} に$ 従い, 組織学的に癌胞巣が単純充実性な いし敷石状，かつ間質結合織が少ないものを充実型 （図 1:A）とし, 癌細胞が小胞巣状, 索状あるいは 個々がばらばらでびまん性に浸潤し，間質結合織が 多いものを非充実型（図1:B）に分類した。また， 両者が混在しているものは優勢であるものを組織型 に採用した。

それぞれ年齢, 性差, 家族歴, 腫瘍最大径, 占拠 部位, 壁深達度, リンパ管侵襲, 静脈侵襲, リンパ 節転移, 朋転移, 腹膜播種, 再発率, 再発部位, 生 存率について比較検討を行った. 術後のフォロー 


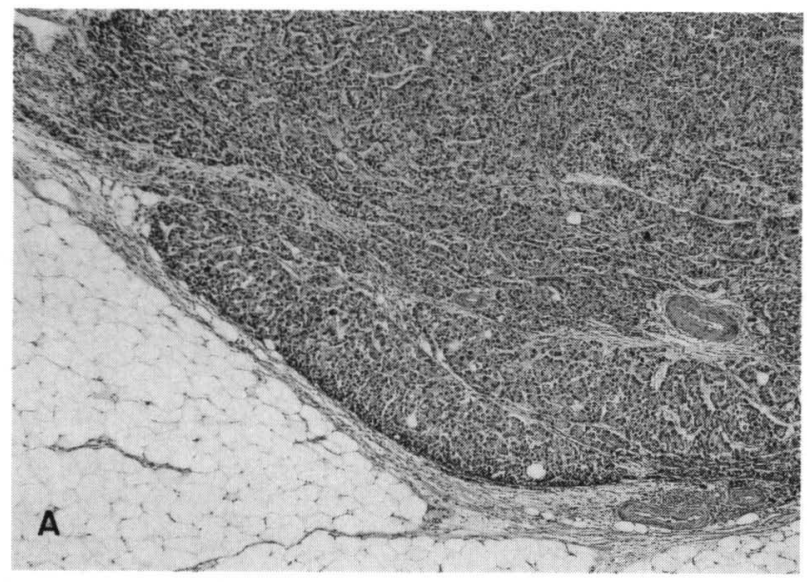

図 1 A：充実型低分化腺癌の組織像 (HE 染色, 40 倍)

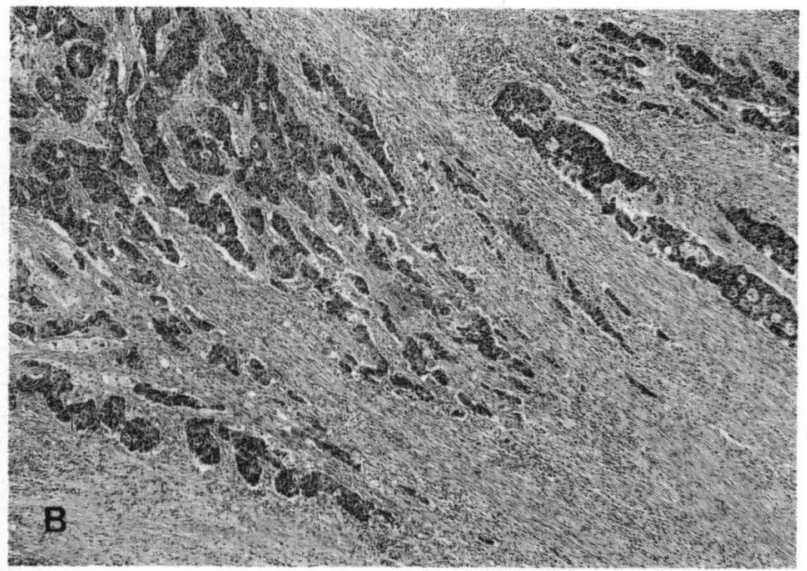

図 1 B : 非充実型低分化腺癌の組織像 (HE 染色, 40 倍)

アップは, 外来診察, 血中 CEA 值測定 (3 カ月〜 1 年毎), 注腸造影または大腸内視鏡検査 $(6$ 力月〜 1 年毎), 腹部超音波検査, 胸腹部 CT 検査 (6 力月～ 1 年毎)で行い, 再発の診断はこれらの画像所見や病 理組織所見を総合して判断した. フォローアップ期 間は低分化腺癌 2 164 力月 (中央值 28.5 力月), 充 実型低分化腺癌 3 164 力月 (中央值 68.5 力月), 非 充実型低分化腺癌 2 125 (22.5 力月), 中分化腺癌 1 $\sim 156$ 力月 (36 力月), 高分化腺癌 1 168 力月（中 央值 48 カ月）であった.

統計学的検討は $\chi^{2}$ 検定を用い, 生存率は KaplanMeier 法で算出し, logrank test にて検定し, $\mathrm{p}<0.05$ を有意差ありとした．また多変量解析として Cox の回帰分析を加え検討した。

\section{結 果}

\section{1. 織型別の臨床病理学的特徴（表 $1 ）$}

低分化腺癌症例の平均年齢は 62 歳で, 男性に多い 傾向が認められたが, 高分化, 中分化腺癌と比較し 有意な差は認められなかった。家族内 (2 親等以内) に大腸癌患者を有する症例は，低分化腺癌 5 例（6.1 $\%)$, 中分化腺癌 17 例 (4.6\%), 高分化腺癌 25 例 (4.0\%)で，3 群間に有意差はなかった。腫瘍最大径 は，低分化腺癌は他の 2 型に比し有意に大きかった $(\mathrm{p}<0.01 \sim 0.001)$. 占拠部位は, 盲腸から横行結腸ま での右側結腸, 下行結腸から S 状結腸までの左側結 腸及び直腸の 3 部位に分けると，低分化腺癌では右 側結腸に多く，他の 2 型は直腸に多かったが有意差 はなかった。また，中等度以上のリンパ管・静脈侵 襲及びリンパ節転移, 腹膜播種を有する症例が低分 化腺癌では他の 2 型より有意に多く $(\mathrm{p}<0.05$ 0.0001)，高分化腺癌と比較すると肝転移症例も有意 に多かった（p<0.001）.

低分化腺癌は他の 2 型に比し有意に予後不良で (logrank test, $\mathrm{p}<0.0001$; 図 2)，5 年累積生存率は 低分化腺癌 $47.2 \%$, 中分化腺癌 $65.7 \%$, 高分化腺癌 $75.0 \%$ であった.

\section{2. 充実型と非充実型低分化腺癌の比較}

表 2 に示すように，平均年齢，性差，腫瘍最大径 は両型に差はなく, 占拠部位は充実型で右側結腸に 多いのに対し，非充実型では直腸及び左半結腸に多 かったが, 有意差は認められなかった。また, リン パ管・静脈侵襲は両者とも中等度以上の侵襲例が約 $80 \%$ 以上を占めており, リンパ節転移及び肝転移は 非充実型が充実型に比し有意に多かった $(\mathrm{p}<0.05)$.

術後再発率は非充実型 $41.5 \%$ （34 例）に対し, 充 実型 $15.9 \%$ (13 例) で有意差がみられた $(\mathrm{p}<0.01)$. また，局所再発は非充実型は充実型に比し有意に多 かった $(\mathrm{p}<0.05$; 表 3$)$. さらに非充実型は充実型に 比し有意に予後不良で (logrank test, $\mathrm{p}<0.05$; 図 $3), 5$ 年累積生存率は, 非充実型は $36.7 \%$ で, 充実型 は $67.7 \%$ であった. Coxの回帰分析により，年齢 (66 歳以上： 65 歳未満), 性別, 腫瘍最大径 $(5.5 \mathrm{~cm}$ 以上: $5.4 \mathrm{~cm}$ 以下), 部位 (右半結腸 : 左半結腸 + 直 腸), 深達度（固有筋層まで：固有筋層を越える）, リンパ節・肝・腹膜転移 (有無), 組織亜分類 (充実 型：非充実型）の 9 因子について解析した結果, 独 立した予後不良因子として, (1)66 歳以上, (2)非充実 型低分化腺癌の 2 項目が抽出された（表 4). 
表 1 組織型別の臨床組織学的特徴

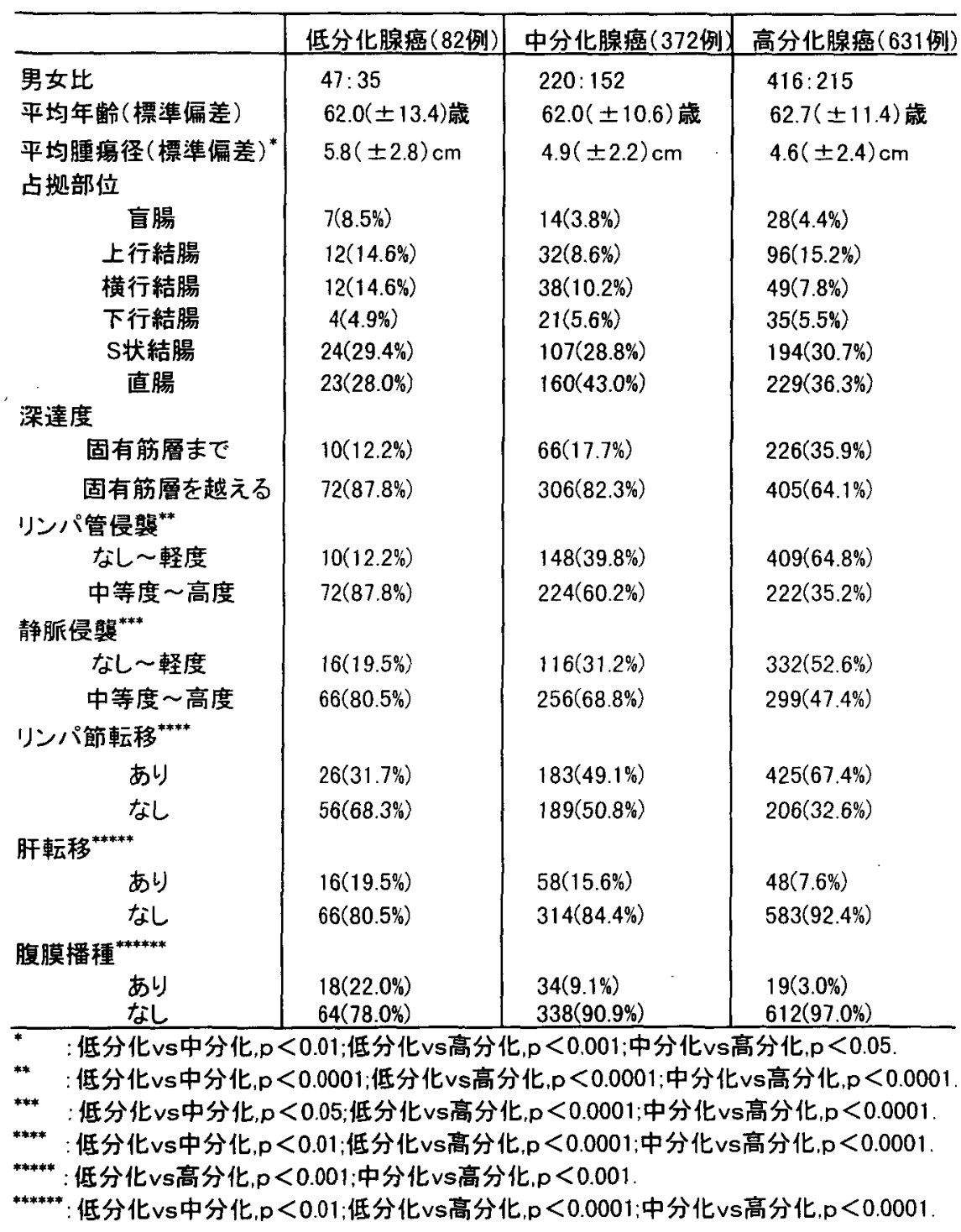

\section{考察}

自験例での全大腸癌中の低分化腺癌の頻度は7.3 \%と低率で，これまでの報告とほほ同様であっ た . 当施設では大腸癌切除材料は带全割し，でき るだけ多くの組織切片を作製しており，組織型は大 腸癌取り扱い規䄪 ${ }^{15)}$ に準じ，最も優勢の分化度を もって, 組織型としているが, 低分化腺癌の頻度の 施設間の差異は作製した切片数にも関連していると 思われる。

低分化腺癌は腫瘍径が他の 2 型に比し大きく，右 側結腸に多いことは自験例も含めほとんどの報告で 共通しており ${ }^{1-3.4-9)}$ ，さらにわれわれの検討では,充
実型低分化腺癌は非充実型に比し，右側結腸に多 かった．清水ら ${ }^{16)}$ は動物発癌実験において, 盲腸, 近 位結腸に低分化腺癌が発生し，遠位結腸には高分化 腺癌が多いことを報告して掞り，発生部位による癌 の分化度の違いを実験的に証明した。また，遺伝性 非ポリポーシス大腸癌では，DNA 複製エラーが癌 発生に関与しており ${ }^{17.18)}$ ，このDNA 複製エラーの 結果生じたマイクロサテライト不安定性を有する大 腸癌は右側結腸の低分化腺癌が多いと報告されてい る $^{19,20)}$. さらに，充実型低分化腺癌 20 例中 18 例 $(90$ \%）にマイクロサテライト不安定性が証明されてお

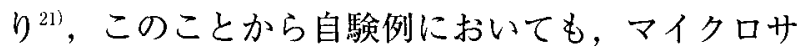
テライト不安定性についての検討が今後必要と考え 


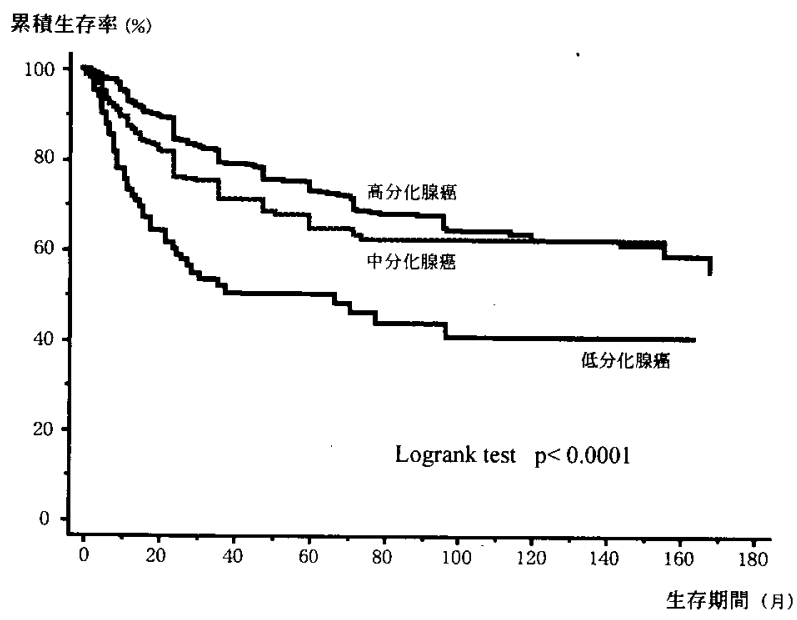

図 2 組織分化度別の累皘生存率

表 2 充実型，非光奏型低分化腺癌の臨床病理学的特徽

\begin{tabular}{|c|c|c|}
\hline & 充実型 (34例) & 非充実型 (48例) \\
\hline 男女比 & $22: 12$ & $25: 23$ \\
\hline 平均年夦(標準偏差) & $61.9( \pm 14.6)$ 雨 & $63.9( \pm 12.1)$ 歳 \\
\hline $\begin{array}{l}\text { 平均腫瘍径(標準偏差) } \\
\text { 占拠部位 }\end{array}$ & $4.5( \pm 2.9) \mathrm{cm}$ & $4.8( \pm 2.3) \mathrm{cm}$ \\
\hline 盲腸 & $4(11.8 \%)$ & $3(6.3 \%)$ \\
\hline 上行結腸 & $7(20.6 \%)$ & $5(10.4 \%)$ \\
\hline 横行結腸 & $7(20.6 \%)$ & $5(10.4 \%)$ \\
\hline 下行結腸 & $1(2.9 \%)$ & $3(6.3 \%)$ \\
\hline S状結腸 & $6(17.6 \%)$ & $14(29.2 \%)$ \\
\hline 直腸 & $9(26.5 \%)$ & $18(37.4 \%)$ \\
\hline 深達度 & & \\
\hline 固有筋層まで & $3(8.8 \%)$ & $7(14.6 \%)$ \\
\hline $\begin{array}{l}\text { 固有筋層を越える } \\
\text { リンパ管侵襲 }\end{array}$ & $31(91.1 \%)$ & $31(85.4 \%)$ \\
\hline なし〜軽度 & $6(17.6 \%)$ & $4(8.3 \%)$ \\
\hline 中等度～高度 & $28(82.4 \%)$ & $44(91.7 \%)$ \\
\hline 静脈侵襲 & & \\
\hline なし〜軽度 & $5(14.7 \%)$ & $11(22.9 \%)$ \\
\hline 中等度～高度 & $29(85.3 \%)$ & $37(77.1 \%)$ \\
\hline リンパ節転移* & & \\
\hline あり & $18(52.9 \%)$ & $38(79.2 \%)$ \\
\hline なし & $16(47.1 \%)$ & $10(20.8 \%)$ \\
\hline 肝転移 ${ }^{* *}$ & & \\
\hline あり & $2(5.9 \%)$ & $14(29.2 \%)$ \\
\hline なし & $32(94.1 \%)$ & $34(70.8 \%)$ \\
\hline 腹膜播種 & & \\
\hline あり & $6(17.6 \%)$ & $11(22.9 \%)$ \\
\hline なし & $28(82.4 \%)$ & $37(77.1 \%)$ \\
\hline
\end{tabular}

られ，低分化腺癌と分化型腺癌のみならず，充実型 と非充実型低分化腺癌でのマイクロサテライト不安 定性陽性率には差異があるものと推定される。

低分化腺癌は分化型に比べ, 浸潤型の肉眼型を示

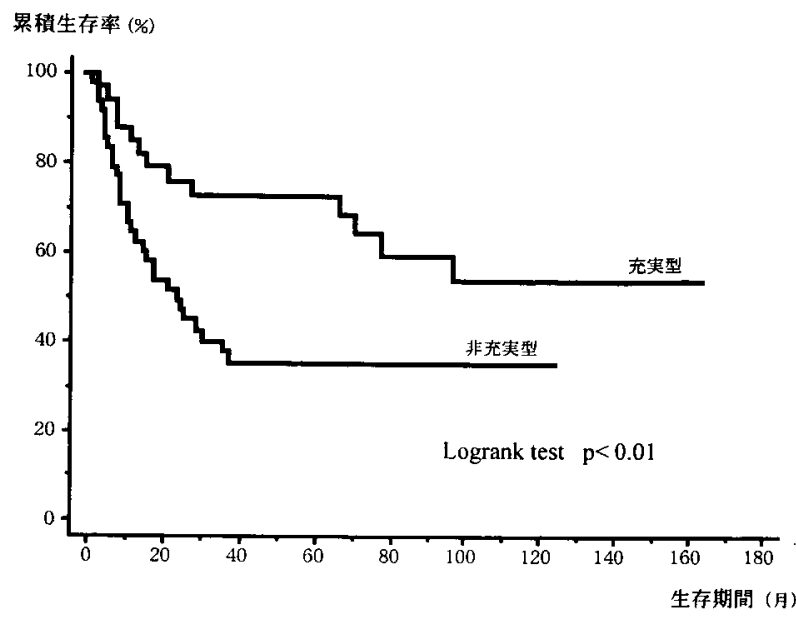

図 3 充実型, 非充実型低分化腺癌の累積生存率

表 3 充実型, 非充実型低分化腺癌の再発形式

\begin{tabular}{l|c|c}
\hline & 充実型(34例) & 非充実型(48例) \\
\hline 局所 $^{*}$ & $1(2.9 \%)$ & $11(22.9 \%)$ \\
リンパ節 & $10(29.4 \%)$ & $18(37.5 \%)$ \\
肝 & $8(23.5 \%)$ & $21(43.8 \%)$ \\
肺 & $2(5.9 \%)$ & $9(18.8 \%)$ \\
腹膜 & $2(5.9 \%)$ & $6(12.5 \%)$ \\
\hline
\end{tabular}

${ }^{*}: \mathrm{p}<0.05$

表 $4 \operatorname{Cox}$ の回帰分析結果

\begin{tabular}{|c|c|c|c|}
\hline & 回帰係数 & $\begin{array}{c}\text { リスク比 } \\
\text { (95\%信頼限界) }\end{array}$ & $\mathrm{p}$ 值 \\
\hline $\begin{array}{l}\text { 66歳以上 } \\
65 \text { 歳以下 }\end{array}$ & -0.946 & $\begin{array}{c}1 \\
0.388 \\
(0.222-0.678) \\
\end{array}$ & 0.009 \\
\hline $\begin{array}{l}\text { 非充実型低分化腺癌 } \\
\text { 充実型低分化腺癌 }\end{array}$ & -0.999 & $\begin{array}{c}1 \\
0.368 \\
(0.191-0.709)\end{array}$ & 0.0028 \\
\hline
\end{tabular}

す例，固有筋層以深浸潤例，リンパ節・肝転移及び 腹膜播種陽性例が多く，予後不良と報告されてお $り^{1.4 \sim 9)}$, 自験例も同様の結果であった。一方, p53 蛋白発現やDNA ploidy patternに関する比較では, 低分化と分化型腺癌では差はみられなかったと報告 されている ${ }^{5.6)}$. 大腸の低分化腺癌の頻度が低いこと から, 充実型, 非充実型（硬性型）に亜分類した検 討は少ないが ${ }^{13.6 .92 .2122)}$ ，非充実型は充実型に比べ，リ ンパ節転移；腹膜播腫陽性例が多く，予後不良とさ れ, 免疫組織化学的な検索で bcl- 2 蛋白発現率が非 
充実型では充実型に比べ有意に低いとの報告がみら れる22).われわれの検討でも再者共にリンパ管侵 襲，静脈侵襲が高度で, 非充実型は充実型に比し有 意にリンパ節転移, 肝転移が多く, 再発率も有意に 高く，予後不良であった，特に，非充実型では充実 型に比し局所再発率が高いことから，前者の組織学 的特徵である浸潤性発育により，切除断端における 顕微鏡レベルでの癌の違残の頻度が高いものと推定 されたささらに，自験例の多変量解析の結果，低分 化腺癌の充実型, 非充実型の覀分類法は独立した子 後因子であることが明らかなり，この分類法は術後 の再発の子測や予後について検討する上で有用と考 えられた。

大塚ら ${ }^{3)}$ は, 低分化腺癌あるいは未分化癌と診断さ れた 64 例の中から 6 例の内分泌細胞癌を抽出し検 討したところ，1 例のみ 4 年 3 力月生存した以外は 極端に予後不良であると報告した．充実型低分化腺 癌と内分秘細胞癌をへマトキシチン・エオジン染色 のみで鑑別することは困難であることから，今後は 充実型低分化腺癌症例では，ルーチンにグリメリウ ス染色ないしクロモグラニンなどの神経内分泌細胞 マーカーを用いた免疫染色を併用し，その中から内 分泌細胞癌を別に抽出する必要があると考えられ る。

本論文の要旨の一部は, 第 56 回日本消化器外科学会総会 において発表した

\section{文献}

1）軽部秀明, 增田英樹, 佐藤史井ほか：大腸低分化腺癌の 臨床病理学的検討一充実型と非充実型の比較につい て一. 日大医誌 $58: 370-376,1999$

2）出江洋介, 川崎恒雄, 丸山祥司ほか：大腸低分化型癌の 臨床病理学的検討. 日臨外医会誌 $55: 1385-1391,1994$

3）大塚正彦, 加藤 洋: 大腸の低・未分化癌の臨床病理学 的検討一分類抢よび内分泌細胞癌との関連について。 日 消外会誌 $25: 1248-1256,1992$

4）池永雅一, 吉川宣輝, 三沜秀行ほ加：大腸低分化腺癌 76 例の検討。日本大腸肛門病会誌 $50: 469-475,1997$
5）神野正博, 坂本浩也, 月岡雄治ほか：大腸低分化腺癌の 臨床病理学的研究. 日本大腸肛門病会誌 $45: 244-247$, 1992

6）中崎隆行, 飛永晃二, 竹富勝郎ほか：大腸低分化腺癌の 臨床病理学的検討. 日臨外会誌 $59: 1995-1999,1998$

7）田中千凱, 大下裕夫, “深田代造: 大腸低分化腺癌の臨床 病理学的検討. 日臨外会誌 $53: 313-317,1992$

8）福島 亘, 小西孝司, 佐原博之ほか：大腸低分化腺癌症 例の検討. 日消外会誌 $26: 1013-1017,1993$

9）平井一郎, 池田栄一, 飯澤 筆ほか: 大腸低分化腺癌, 印環細胞癌の臨床病理学的検討. 日消外会誌 28:805812,1995

10）滝澤登一郎，小池盛雄，船田信顕ほか：胃癌の組織学的 多様性と転移・浸潤に関する病理形態学的考察. 外科治 療 $77: 29-36,1997$

11）市川一仁，平林か㧍る，上田善彦ほか：增殖因子と接着 因子からみた, いわゅる PEN 型早期胃癌とスキルス胃 癌の同質性. 消化器内視鏡 $10: 323-329,1998$

12）広瀬和郎, 向 仁一, 松本俊彦ほか: 間質結合織の程度 からみた胃の低分化腺癌の阽床病理学的検討. 日消外会 誌 $20: 849-855,1987$

13）甲田賢治, 喜納 勇：胃低分化腺癌 (por) の亜分類の臨 床病理学的研究. 胃と腸 $10: 1167-1172,1991$

14）日本胃癌学会編：胃癌取り扱い規約 1999 年度（改定第 13 版)，金原出版，東京， 1999

15）大腸癌研究会編：大腸癌取り扱い規約, 第 6 版. 金原出 版, 東京, 1998

16）清水 豊, 中澤三郎：DMH 誘発ラット大腸癌発生に及 ぼす食䬣性因子及び䀺便中胆汁酸の影響. 日消誌 82 : 2554-2561, 1985

17) Peltomäki $P$, Aaltonen LA, Sistonen $P$, et al : Genetic mapping of a locus predisposing to human colorectal cancer. Science $260: 810-812,1993$

18) Aaltonen LA, Peltomäki, Leach FS, et al: Clues to the pathogenesis of familial colorectal cancer. Science 260 : 812-816, 1993

19) Thibodeau SN, Schaid BD : Microsatellite instability in cancer of the proximal colon. Science $260: 816-819,1993$

20) Lothe RA. Peltomäki P, Meling GI, et al : Genomic instability in colorectal cancer : Relationship to clinicopathological variables and family history. Cancer Res 53 : 5849-5852, 1993

21) Lanza G, Gafä R, Matteuzzi M, et al : Medullary-type poorly differentiated adenocarcinoma of the large bowel : A distinct clinicopathologic entity characterized by microsatellite instability and improved survival. J Clin Oncol $17: 2429-2438,1999$

22) Sugao Y, Yao T, Kubo C, et al: Improved prognosis of solid-type poorly differentiated colorectal adenocarcinoma : a clinicopathological and immunohistochemical study. Histopathology 31 : 123-133, 1997 


\title{
Clinicopathologic Characteristics of Poorly Differentiated Adenocarcinoma of the Colorectum : Prognostic Significance of Solid and Non-solid Types of Poorly Differentiated Adenocarcinoma
}

\author{
T. Nakamura, Y. Otani, H. Mitomi ${ }^{11}$, H. Kanazawa, K. Nemoto, \\ Y. Kokuba, M. Sada ${ }^{2}$, A. Ihara, A. Kakita, \\ Departments of Surgery, School of Medicine, \\ ${ }^{1}$ Departments of Surgery, Pathology School of Medicine, \\ ${ }^{2)}$ Departments of Surgery, Internal School of Medicine,
}

AIMS The aim of this work was to clarify clinicopathologic features of poorly differentiated adenocarcinomas of the colorectum, which were especially subclassified into solid and nonsolid types, in comparison with well to moderately differentiated adenocarcinomas.

METHODS A total of 1085 patients with colorectal carcinoma ( 82 poorly differentiated, 631 well differentiated, and 372 moderatery differentiated adenocarcinomas) that received surgery at Kitasato University East Hospital, between 1986 and 1999, were investigated for clinicopathologic variables. Comparative study was performed between 34 solid type and 48 non-solid type poorly differentiated adenocarcinomas. Data were analyzed by univariate and multivariate statistics.

RESULTS Larger tumor and metastases to lymph nodes, liver, or peritoneum were more frequently observed in poorly differentiated type than in other types of adenocarcinomas. Five-year survival was significantly worse in the former $(47 \%)$ than in the latter (well differentiated type, $75 \%$; moderately differentiated type, $66 \%$ ). Non-solid type poorly differentiated adenocarcinomas frequently showed lymph node liver metastases compared with solid type. Five-year survival was significantly worse in the non-solid type (37 $\%)$ than in the solid type (68\%). Cox 's logistic regression multivariate analysis showed that non-solid type and older patients ( $\geqq 66 \mathrm{yrs}$ ) were statistically significant worse predictors.

CONCLUSIONS Poorly differentiated adenocarcinomas were aggressive tumors associated with frequent metastases. subclassification of these tumors into non-solid and solid types is an independent prognostic predictor. 